Global Conferences Series:

Social Sciences, Education and Humanities (GCSSSEH), Volume 6, 2020

International Conference Fakultas Tarbiyah dan Keguruan Universitas Islam Negeri Imam Bonjol Padang (ICFTKUINIBP) 2020

DOI: https://doi.org/10.32698/icftk416

\title{
Development of Four-Tier Tet Formatted Diagnostic Test Instruments to Identify Misconceptions in Gas Kinetic Theory Materials and Termdynamic Law
}

\section{Pengembangan Instrumen Tes Diagnostik Berformat Four-Tier Tet Untuk Mengidentifikasi Miskonsepsi Pada Materi Teori Kinetik Gas dan HukUm Termdinamika}

\author{
Raudahtul Jannah ${ }^{\text {a }}$, Sandijal Putra ${ }^{a}$, M. Abrar \\ ${ }^{a}$ Universitas Islam Negeri Imam Bonjol, Padang, Indonesia \\ E-mail: raudahtuljannah@uinib.ac.id
}

\begin{abstract}
This study developed a four-tier test diagnostic test instrument to identify students' misconceptions on the material of the kinetic theory of gases and the laws of thermodynamics. This research is a development research using the 4D model. The 4D development model consists of four stages, namely: 1) Define, 2) Design (Design), 3) Develop (Development), 4) Disseminate (Spread). The instrument used in this study The instrument used in this study was a test instrument quality assessment sheet for material experts and evaluation experts. Assessment of product quality uses a Likert scale with 5 scales made in the form of a checklist. The results of the research developed were a four-tier test diagnostic test instrument to identify student misconceptions on the material of gas kinetic theory and the laws of thermodynamics. This four-tier test diagnostic test instrument consists of 16 items. Item validation includes the content validity in terms of material, construction, and language / culture aspects, as well as the suitability between the questions on the test and the indicators obtained from the consideration of expert lecturers. The practicality test of the Physics Diagnostic Test questions was given to 2 physics educators and 12 students of class XI IPA1 MAN 1 West Pasaman assessed from the aspects of ease and legibility of the questions in the implementation of the test. The effectiveness test was tested on 20 students of class XI IPA 1 MAN 1 West Pasaman by providing an Instrument for a Physics Diagnostic Test. The results of this study have produced Physics Diagnostic Test questions that are valid, practical and effective. The Physics Diagnostic Test item is valid both in terms of material, construction and language with an average value of $89.7 \%$ with a very valid category. The practicality of the Physics Diagnostic Test items has an average value of $81.8 \%$ with the practical category, while for the effectiveness of the product, the validity of the questions is $80 \%$, the reliability of the questions is 0.78 , the level of difficulty and the distinguishing power of the questions are good on each point of the problem. generated with an average value of $24 \%$.
\end{abstract}

Keywords: Diagnostic test, four-tier test, kinetic theory of gases, thermodynamics, misconceptions

\section{INTRODUCTION}

Salah satu faktor terpenting yang menghalang pembelajaran yang bermakna dan permanen siswa adalah kesalahpahaman (Kose, 2008). Miskonsepsi merupakan suatu istilah yang merujuk kepada perbedaan pemikiran antara konsep yang dimiliki siswa dengan konsep dari teori sains yang ditetapkan ahli (Gurel, 2015). Pesman mendefinisikan miskonsepsi sebagai prasangka atau pemahaman tentang suatu konsep yang diyakini secara kuat namun konsep yang diyakini tidak sesuai dengan konsep-konsep ilmiah para ahli. Miskonsepsi dapat muncul dari pengalaman sehari-hari yang dialami siswa ketika berinteraksi dengan lingkungan sekitarnya. (Afif \& Nur Fadhillah 2007) Melalui pengalaman tersebut siswa akan membangun teori sendiri di dalam pikirannya yang belum tentu benar. Apabila intuisi yang terbentuk tidak benar, akan sangat sulit untuk diperbaiki karena tanpa sengaja secara konsisten konsep

Copyright $@ 2020$, the Authors. Published by Redwhite Press.

Page | 153

This is an open access article under the CC BY-NC license

(http://creativecommons.org/licenses/by-nc/4.0). 
fisika yang salah tersebut telah menjadi pegangan (Fatriyani dkk, 2015). Oleh, karena itu untuk mengetahui adanya kesulitan atau masalah yang dihadapi siswa ini diperlukan tes diagnostik (Zhao, 2013).

Tes diagnostik dapat digunakan untuk mengidentifikasi masalah atau kesulitan siswa dan merencanakan tindak lanjut berupa upayaupaya pemecahan masalah atau kesulitan yang telah teridentifikasi (Gurel, Erylmaz, \& McDermott, 2015). Tes diagnostik utamanya adalah untuk mengetahui kekuatan dan kelemahan siswa dan memberi masukan kepada guru dan siswa untuk membuat keputusan terkait dengan perbaikan proses mengajar dan proses belajar (Zhao, 2013). Penggunaan tes diagnostik di awal maupun di akhir pembelajaran dapat membantu guru menemukan miskonsepsi siswa pada materi yang dipelajari (Lin, 2004). Tes diagnostik yang baik dapat memberikan gambaran akurat mengenai miskonsepsi yang dialami siswa berdasarkan informasi kesalahan yang dibuatnya. Pertanyaan diagnostik yang baik tidak hanya menunjukkan bahwa siswa tidak memahami bagian materi tertentu, akan tetapi juga dapat menunjukkan bagaimana siswa berpikir dalam menjawab pertanyaan yang diberikan meskipun jawaban mereka tidak benar (Law and treagust, 2010). Salah satu cara yang bisa digunakan untuk mengungkapkan miskonsepsi siswa ialah tes pilihan ganda dengan alasan terbuka (Sion, 2008). Namun, proses pengolahan data untuk alasan terbuka kurang efisien karena guru juga harus melakukan wawancara untuk menyinkronkan jawaban yang siswa tulis apakah karena mengalami miskonsepsi atau karena ketidaktahuan konsep. Oleh sebab itu, digunakanlah tes diagnostik miskonsepsi berformat fout-tier (Celeon.I S \&Subramaniam, 2010)

Four tier test dikembangkan oleh Caleon dan Subramaniam yang dapat mendiagnosis miskonsepsi secara langsung tanpa harus melakukan wawancara pada siswa. Four-tier diagnostic test (tes diagnostik empat tingkat) merupakan pengembangan dari tes diagnostik pilihan ganda tiga tingkat. (Fatriyani dkk, 2017). Four-tier diagnostic test (FTDT) terdiri dari empat tingkat (four-tier). Tier-1 pada FTDT merupakan butir soal dan jawaban soal dalam bentuk pilihan ganda. Tier-2 merupakan tingkat keyakinan siswa dalam memilih jawaban pada Tier-1. Tier-3 adalah ungkapan alasan siswa dalam memlih jawaban pada Tier-1. Tier-4 menambahkan tingkat keyakinan yang akan dipilih siswa dalam menjelaskan alasan pada Tier-3. Tambahan dari keyakinan untuk tes diagnostik menuntut para siswa lebih berhati-hati dalam memilih jawaban (Yusrizal \& Halim, 2017). Keunggulan yang dimiliki tes diagnostik pilihan tingkat adalah melalui tes diagnostik empat tingkat guru dapat: (1) membedakan tingkat keyakinan jawaban dan tingkat keyakinan alasan yang dipilih siswa sehingga dapat menggali lebih dalam tentang kekuatan pemahaman konsep siswa, (2) mendiagnosis miskonsepsi yang dialami siswa lebih dalam, (3) menentukan bagian-bagian materi yang memerlukan penekanan lebih, (4) merencanakan pembelajaran yang lebih baik untuk membantu mengurangi miskonsepsi siswa. (Fatriyani dkk, 2015)

\section{METHOD}

Penelitian ini dikategorikan sebagai penelitian pengembangan. Perangkat pembelajaran yang dikembangkan adalah instrumen tes diagnostik berformat four tier test untuk mengidentifikasi miskonsepsi siswa pada materi teori kinetik gas dan hukum termodinamika. Model pengembangan yang digunakan yaitu model pengembangan 4D (four D model) oleh S. Thigarajan, Dorothy S. Semmel, dan Melvyn I. Semmel (1974). Model pengembangan 4D terdiri dari 4 tahap utama yaitu: (1) Define (Pendefinisian), (2) Design (Perancangan), (3) Develop (Pengembangan), (4) Disseminate (Penyebaran).

Instrumen pengumpulan data pada penelitian ini dilakukan dengan beberapa teknik yaitu dapat di lihat pada tabel 1 berikut:

Tabel 1. Instrumen Pengumpulan Data

\begin{tabular}{lll}
\hline No & Kriteria & Instrumen \\
\hline 1 & Valid & a. Lembar penilaian instrumen validasi \\
& & b. Lembar penilaian instrumen praktikalitas \\
2 & Praktis & a. Angket praktikalitas oleh pendidik \\
3 & Efektif & b. Angket praktikalitas oleh peserta didik \\
\hline
\end{tabular}

Teknik Pengumpulan data yang digunakan pada penelitian ini yaitu dengan menggunakan angket yang terdiri dari angket validitas, angket praktikalitas dan angket efektifitas. Angket validitas diberikan kepada 5 orang validator ( 2 orang validator materi/isi, 2 orang validator konstruksi dan satu orang validator bahasa). Angket praktikalitas diisi oleh 2 orang pendidik dan peserta didik. Angket efektifitas diisi oleh peserta didik berguna untuk mengidentifikasi miskonsepsi yang dialami peserta didik.

Jenis data yang dikumpulkan pada penelitian ini ada dua yaitu data kuantitatif dan data kualitatif. Data kuantitatif diperoleh dari hasil penilaian data angket, sedangkan data kualitatif diperoleh dari saran atau 
komentar validator dan praktisi. Pengolahan data kualitatif diolah dengan menggunakan teknik deskriptif kualitatif. Data yang di analisis kuantitatif adalah data analisis angket penilaian/tanggapan dari validasi dan ujicoba produk.

Data yang terkumpul dianalisis menggunakan teknik skala Likert dengan kategori positif, yaitu pernyataan positif memperoleh bobot tertinggi sebagai berikut:

Tabel 2. Bobot Pernyataan

\begin{tabular}{ll}
\hline Pernyataan & Bobot Pernyataan \\
\hline Sangat setuju & 4 \\
Setuju & 3 \\
Tidak setuju & 2 \\
Sangat tidak setuju & 1 \\
\hline
\end{tabular}

Nilai akhir validasi dianalisis dalam skala (0-100) yang didapatkan dari rumus (1) : $\mathrm{V}=\frac{X}{Y} \times 100 \%$

Dengan V adalah Persentase Skor yang diperoleh, $\mathrm{X}$ adalah Skor yang diperoleh dan Y adalah Skor maksimum.

Nilai akhir ini dirujuk pada interval penentuan kevalidan, kepraktisan, keefektifan ditunjukkan pada Tabel 3 berikut ini:

Tabel 3. Kriteria Tingkat Kevalidan, Kepraktisan, Keefektifan

\begin{tabular}{ccl}
\hline Interval & Kategori \\
\hline & $76-100$ & Sangat Valid \\
$51-75$ & Valid \\
$26-50$ & Kurang Valid \\
$0-25$ & Tidak valid \\
\hline
\end{tabular}

Penilaian efektivitas dianalisis berdasarkan penelitian yang dikembangkan oleh Fratiwi fkk berupa tabel kriteria pemahaman siswa. Kriteria untuk menentukan siswa paham konsep, tidak paham konsep, dan miskonsepsi dapat dilihat pada Tabel 1

Tabel 4. Kombinasi Jawaban Four-tier test

\begin{tabular}{|c|c|c|c|c|c|}
\hline \multirow[t]{3}{*}{ No } & \multirow{5}{*}{ Kategori } & \multicolumn{4}{|c|}{ Kombinasi Jawaban } \\
\hline & & & Confidence & & Confidence \\
\hline & & Jawaban & Ratingjawaban & Alasan & Ratingalasan \\
\hline 1 & & Benar & Yakin & Salah & Yakin \\
\hline 2 & & Benar & Tidak & Salah & Yakin \\
\hline 3 & \multirow[t]{6}{*}{ Miskonsepsi } & Salah & Yakin & Salah & Yakin \\
\hline 4 & & Benar & Tidak & Salah & Yakin \\
\hline 5 & & Benar & Yakin & Benar & Tidak \\
\hline 6 & & Benar & Yakin & Salah & Tidak \\
\hline 7 & & Benar & Tidak & Benar & Yakin \\
\hline 8 & & Benar & Tidak & Benar & Tidak \\
\hline 9 & \multirow[t]{5}{*}{ Paham sebagian } & Benar & Tidak & Salah & Tidak \\
\hline 10 & & Salah & Yakin & Benar & Tidak \\
\hline 11 & & Salah & Yakin & Salah & Tidak \\
\hline \multirow[t]{2}{*}{12} & & Salah & Tidak & Benar & \\
\hline & & & & Tidak & \\
\hline 13 & & Salah & Tidak & Salah & Tidak \\
\hline 14 & paham & Salah & Yakin & Benar & Yakin \\
\hline 14 & konsep & Salah & Tidak & Benar & Yakin \\
\hline 16 & Paham & Benar & Yakin & Benar & Yakin \\
\hline
\end{tabular}

Analisis yang dilakukan sesuai dengan Tabel 4 untuk mentukan siswa yang paham, paham sebagiab tidak paham, miskonsepsi menggunakan teknik persentase berikut: 


$$
P=\frac{S}{J S} X 100 \%
$$

Keterangan:

$\mathrm{P}=$ persentase jumlah siswa pada paham konsep, paham sebagian tidak paham konsep, dan miskonsepsi

$\mathrm{S}$ = banyaknya siswa pada paham konsep, paham sebagian tidak paham konsep, dan miskonsepsi

Js $=$ jumlah seluruh siswa peserta tes

\section{HASIL DAN DISKUSI}

Data nilai kevalidan, praktis dan efektif dapat dilihat pada uraian berikut:

\section{Uji Validitas}

Dilihat dari angket penilaian validasi dosen terhadap Instrumen Tes Diagnostik berformat Four-Tier test. Empat indikator yang digunakan adalah komponen kebahasaan, isi/materi, konstruksi, miskonsepsi. Keempat indikator tersebut dijabarkan dalam beberapa pernyataan.

\section{Komponen Kebahasaan}

Indikator komponen kebahasaan menyelidiki aspek penggunaan bahasa dalam instrumen tes diagnostik berformat Four-tier test lima pernyataan. Nilai untuk setiap pernyataan pada indikator penggunaan bahasa pada media dapat dilihat pada grafik dibawah ini :

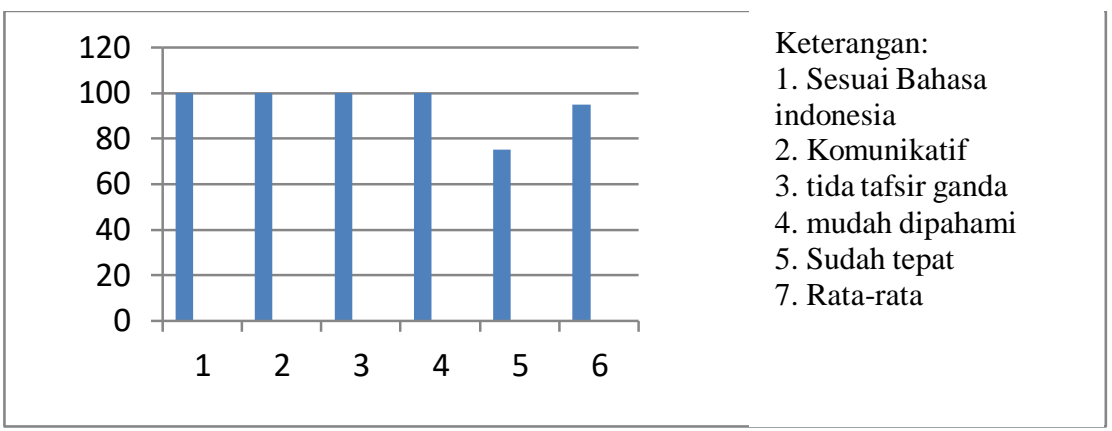

Grafik 1. Hasil Uji Validitas Bahasa

Hasil dari uji validitas bahasa oleh satu orang validator diperoleh hasil yaitu 95\%. Menurut tabel validitas dari Sukardi (2010) nilai rentang 95\% termasuk kategori sangat valid. Produk sudah dapat digunakan sebagai media pembelajaran dapat dilanjutkan ke tahap uji praktikalitas produk.

\section{Uji Validitas Isi/ Materi}

Skor terendah untuk setiap pernyataan validitas isi adalah 2 dan skor tertinggi adalah 4 . Skor setiap pernyataan yang diperoleh dapat dikonversi ke dalam bentuk nilai sehingga nilai terendah adalah 25 dan nilai tertinggi adalah 100. Data hasil uji validitas isi dapat dilihat pada grafik dibawah ini

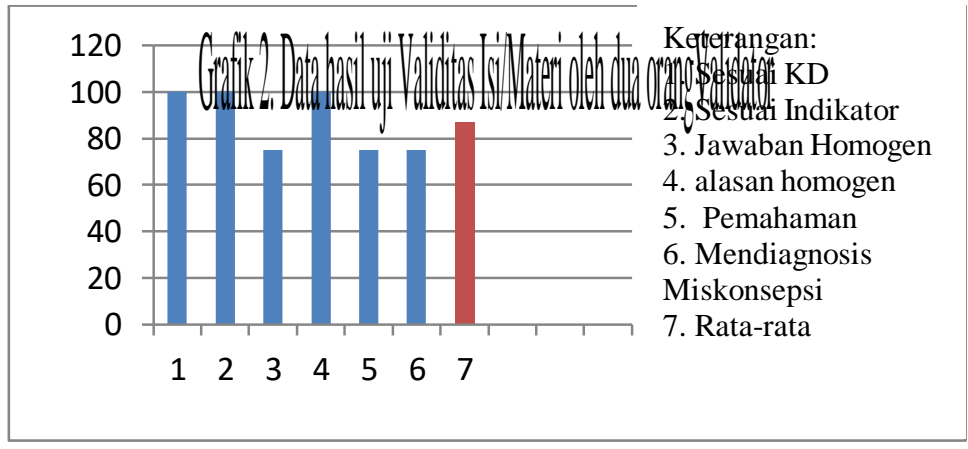

Grafik 2. Data hasil uji Validitas Isi/Materi oleh dua orang Validator 
Grafik 2 menunjukkan nilai rata-rata hasil validasi materi/isi dari 1 orang validator. Hasil rata-rata yang diperoleh dari 2 orang validator adalah $87 \%$ dengan kategori sangat valid. Produk sudah dapat digunakan dan dapat dilanjutkan ke tahap uji praktikalitas produk.

\section{Uji Validitas Konstruksi}

Uji Validitas media diberikan kepada 2 orang validator dengan menggunakan angket. Indikator validitas Konstruksi instrumen tes berformat Four-Tier test 2 dengan dengan 13 pernyataan. Hasil uji validitas media oleh 2 orang validator dapat dilihat pada grafik 3 berikut.

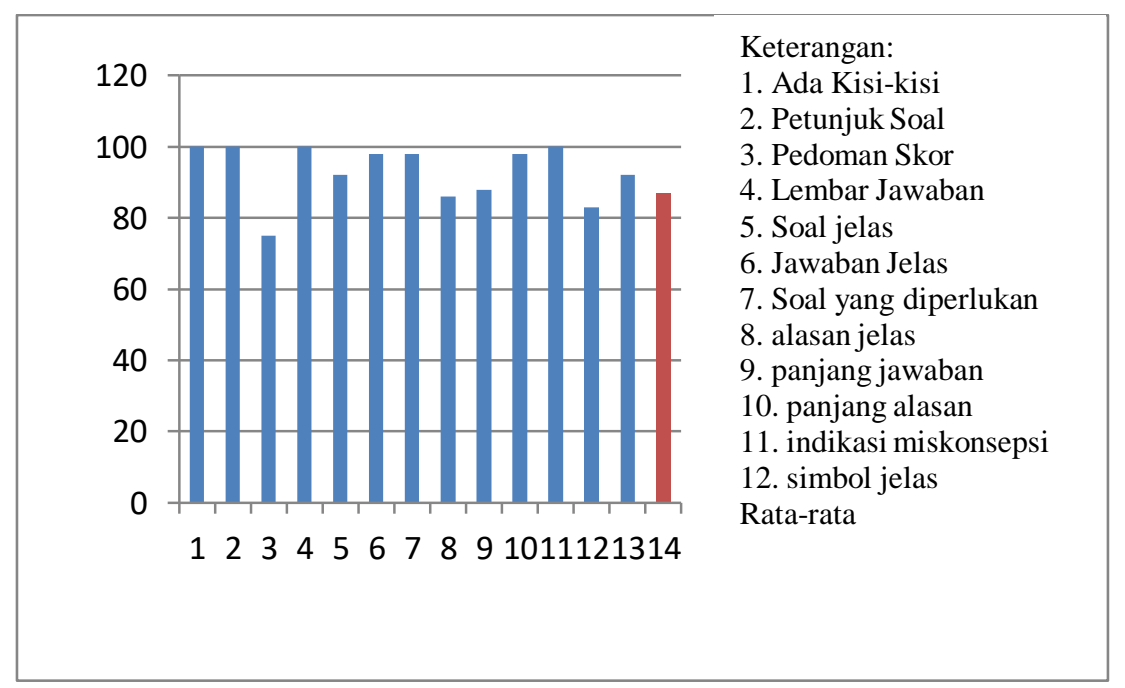

Grafik 3. Hasil angket validitas media

Hasil angket validitas media yang diisi oleh 2 orang validator diperoleh persentase $87 \%$ dengan kategori sangat valid. Sehingga Soal tersebut dapat digunakan ke tahap praktikalitas. Saran yang diberikan oleh validator media dijadikan sebagai pedoman untuk perbaikan media ke arah yang lebih baik.

\section{Uji Vliditas Miskonsepsi}

Uji Validitas miskonsepsi diberikan kepada 1 orang validator dengan menggunakan angket. Indikator validitas Konstruksi instrumen tes berformat Four-Tier test dengan 6 pernyataan. Hasil uji validitas media oleh 2 orang validator dapat dilihat pada grafik 4 berikut.

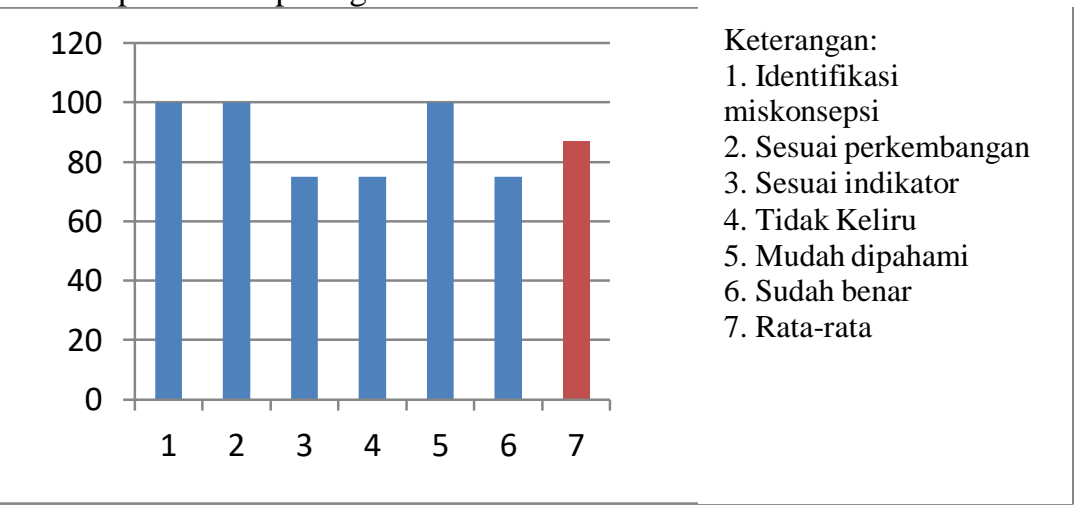

Grafik 4. Hasil Uji Validitas miskonsepsi

Berdasarkan penilaian validitas yang diberikan kepada 5 orang validator terdapat 4 variabel penilaian, yaitu validitas materi/isi, validitas media/kontruksi, validitas miskonsepsi dan validitas bahasa. Nilai rata-rata validitas instrumen tes diagnostik berformat four-tier test keempat variabel validitas produk dapat di lihat pada grafik 4 berikut: 


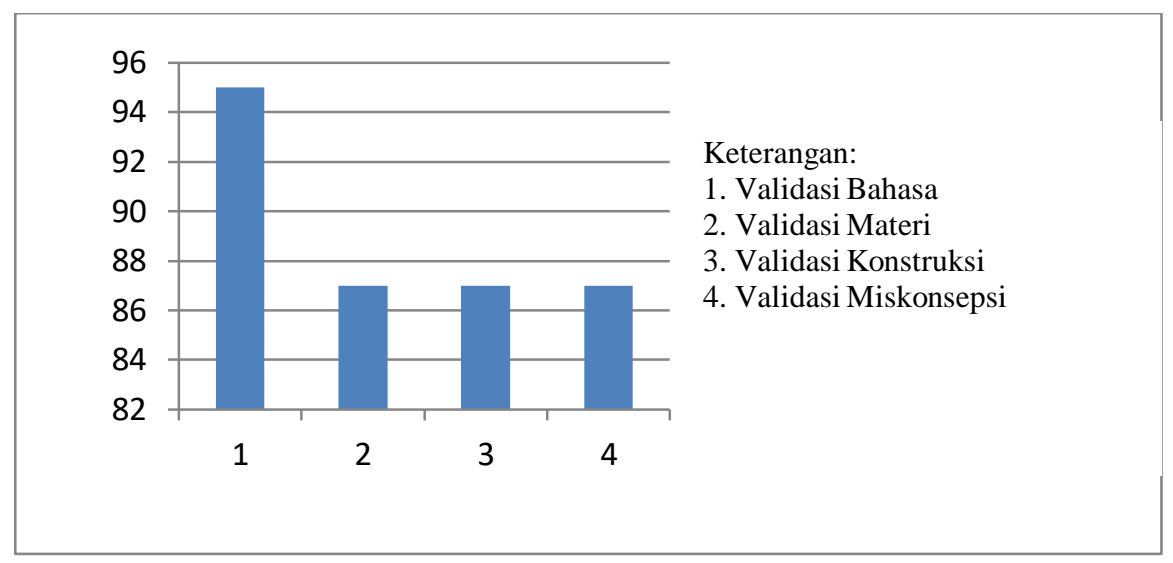

Grafik 5. Nilai Rata-rata Validitas Instrumen Tes

\section{Uji Praktikalitas}

Instrumen Tes diagnostik yang sudah divalidasi kemudian dilakukan uji praktikalitas. Hasil uji praktikalitas terhadap soal instrumen tes diagnostik berformat four-tier test terbagi atas dua yaitu uji praktikalitas oleh pendidik fisika MAN I Pasaman Barat dan uji praktikalitas oleh peserta didik kelas XI MAN I Pasaman Barat.

Uji praktikalitas diperoleh dari penyebaran angket yang di isi oleh 2 orang pendidik fisikadengan 6 pernyataan dan 12 orang peserta didik dengan 7 pernyataan. Data yang diperoleh dari hasil praktikalitas instrumen tes diagnostik berformat four-tier test oleh pendidik dapat di lihat pada grafik 6 berikut:

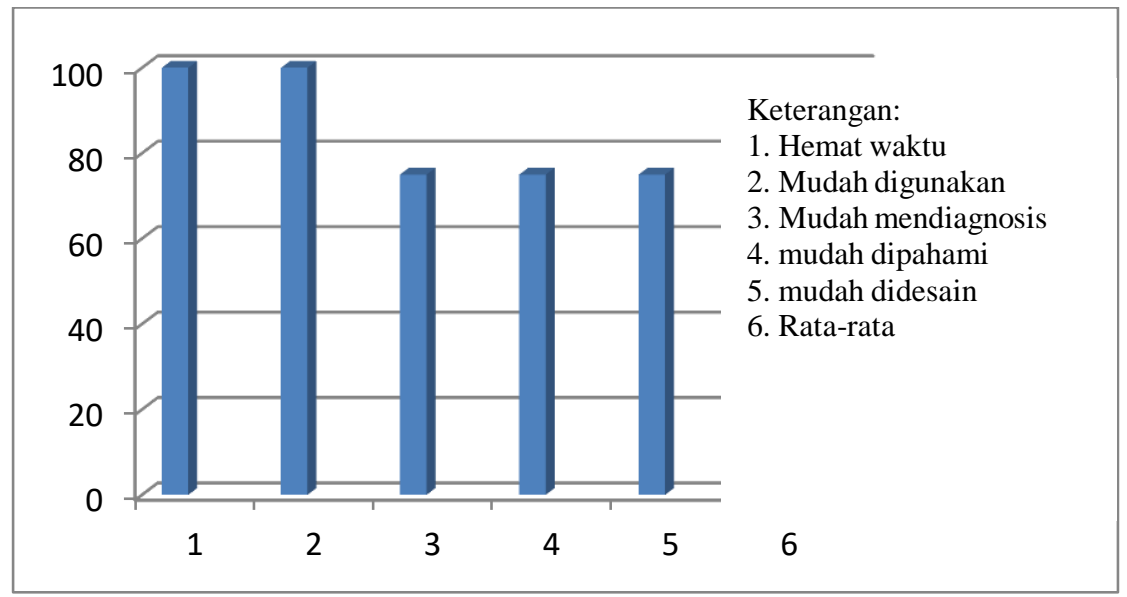

Grafik 6. Praktikalitas Masing-masing Indikator Produk Oleh Pendidik

Grafik di atas menunjukan 5 indikator praktikalitas produk oleh pendidik. Nilai hasil uji praktikalitas instrumen tes diagnostik berformat four-tier test oleh 2 orang pendidik MAN I Pasaman Barat diperoleh hasil $87 \%$ dengan kategori sangat praktis. Penilaian praktikalitas oleh 12 orang peserta didik kelas XI MAN I Pasaman Barat diperoleh hasil 76\% dengan kategori praktis. Hal ini menunjukkan instrumen tes diagnostik berformat four-tier test praktis digunakan,. Uji praktikalitas produk oleh peserta didik diberikan kepada 12 orang peserta didik di kelas XI MAN I Pasaman Barat. Hasil analisis praktikalitas produk oleh peserta didik dapat dilihat dari grafik 7 :

Pada Grafik 7 nilai hasil angket praktikalitas peserta didik yang diisi oleh 12 orang peserta didik didapatkan hasil $76 \%$ dengan kategori praktis. Produk sudah dapat digunakan sebagai soal tes diagnostik fisika. Adapun saran-saran dari peserta didik tersebut dijadikan sebagai pedoman untuk perbaikan media pembelajaran yang dikembangkan. 


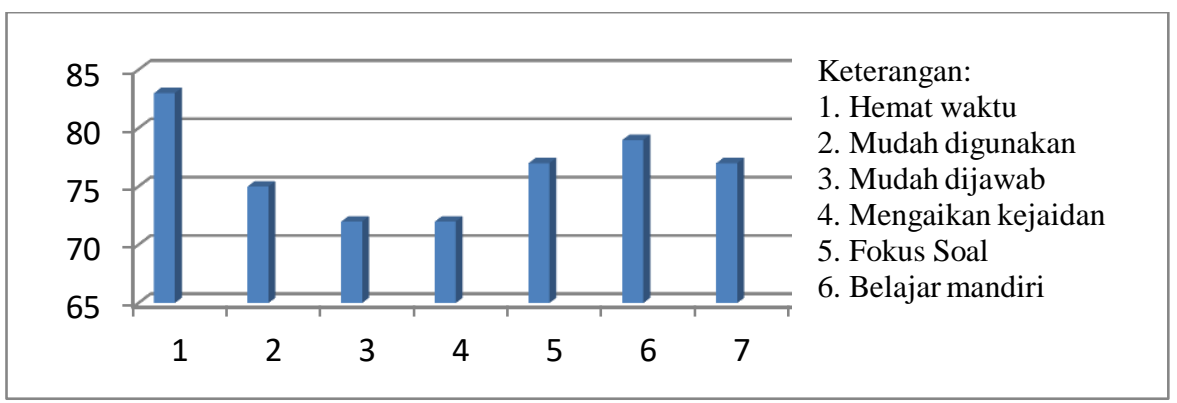

Grafik 7. Hasil Uji Praktikalitas oleh Peserta Didik

\section{Uji Efektifitas}

Uji Efektifitas digunakan untuk melihat paham atau terjadina miskonsepsi pada peserta didik. Uji efejtifitas ini mengunakan butir soal 20 buah tentang materi teori kinetik gas dan hukum termodinamika Data hasil uji efektifitas dari 20 peserta didik di MAN I Pasaman Barat kelas XI dapat dilihat pada tabel dan grafik 7 berikut ini. Selanjutnya dilakukan uji coba kepada 20 siswa XI IPA 2 MAN 1 Pasaman Barat. Uji coba dilakukan untuk mengidentifikasi miskonsepsi siswa berdasarkan hasil uji coba yang telah dilakukan tersebut dapat diketahui tingkat konsepsi siswa sebagai berikut pada tabel dimana P(paham), PS(Paham Sebagian), TPK(Tidak paham konsep), dan M(Miskonsepsi).

Tabel 5. Jumlah Siswa Paham, paham sebagian, Miskonsepsi, dan Tidak Paham Konsep

\begin{tabular}{lllll}
\hline & Presentase \% & M & TPK \\
\cline { 2 - 4 } Siswa ke- & P & PS & 20 & 0 \\
$\mathbf{1}$ & 30 & 50 & 15 & 0 \\
$\mathbf{2}$ & 25 & 60 & 20 & 0 \\
$\mathbf{3}$ & 25 & 55 & 20 & 5 \\
$\mathbf{4}$ & 30 & 45 & 30 & 0 \\
$\mathbf{5}$ & 30 & 50 & 30 & 10 \\
$\mathbf{6}$ & 20 & 45 & 25 & 5 \\
$\mathbf{7}$ & 20 & 45 & 15 & 0 \\
$\mathbf{8}$ & 25 & 60 & 30 & 0 \\
$\mathbf{9}$ & 25 & 45 & 25 & 5 \\
$\mathbf{1 0}$ & 20 & 50 & 25 & 10 \\
$\mathbf{1 1}$ & 20 & 45 & 20 & 5 \\
$\mathbf{1 2}$ & 30 & 45 & 15 & 5 \\
$\mathbf{1 3}$ & 25 & 55 & 20 & 5 \\
$\mathbf{1 4}$ & 30 & 45 & 15 & 10 \\
$\mathbf{1 5}$ & 25 & 45 & 20 & 5 \\
$\mathbf{1 6}$ & 25 & 50 & 25 & 0 \\
$\mathbf{1 7}$ & 30 & 45 & 20 & 0 \\
$\mathbf{1 8}$ & 20 & 60 & 40 & 10 \\
$\mathbf{1 9}$ & 5 & 45 & 40 & 15 \\
$\mathbf{2 0}$ & 15 & 30 & 480 & 90 \\
Total & 470 & 965 & & \\
\hline Prsent & & 50 &
\end{tabular}

Presentase level konsepsi siswa dapat dilhat pada gambar 1 


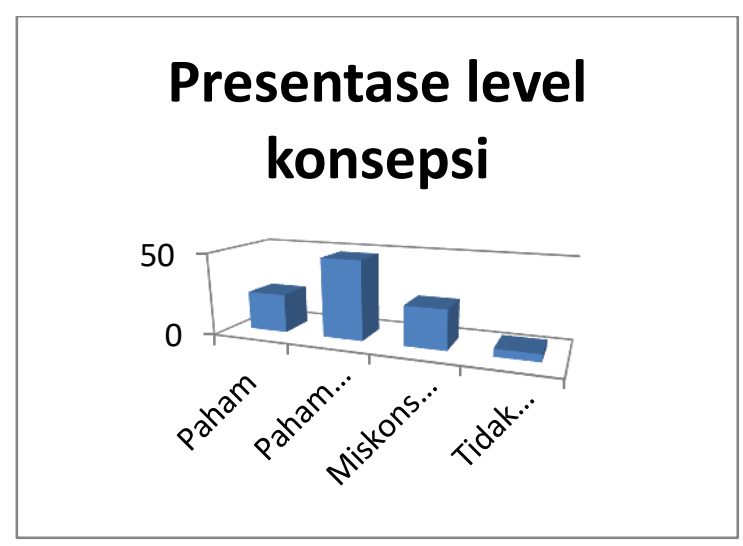

Grafik 8. Diagram level konsepsi siswa

Berdasarkan tabel dan dilihat dari gambar 1, diketahui bahwa siswa dari nomor 1-20 mayoritas kurang memahami materi kinetik gas dan hukum termodinamika terbukti bahwa presentase paham konsep hanya sebesar 0,00-23,5 \%. Diikuti jumlah presentase siswa paham sebagian sebesar 0,00-48,24 \%, miskonsepsi presentaseya 0,00-24\%. Sedangkan untuk tidak paham konsep sebesar 4,6\%.

\section{SIMPULAN}

Berdasarkan hasil penelitian yang dilakukan oleh Peneliti, dapat disimpulkan sebagai berikut, Instrumen Tes diagnostik berformat Four Tier Test yang telah dikembangkan dikategorikan valid atau layak dan siswa yang mengalami miskonsepsi sebesar 24\%, Paham Konsep $23 \%$, paham Sebagian 48\%, dan Tidak paham konsep $4,6 \%$.

\section{REFERENCES}

Afif, Nur Faadhilah, dkk. (2017)."Developing energy and momentum conceptual survey (EMCS) with fourtier diagnostic test items." 2017, doi:10.1063.

Caleon, I. S. \& Subramaniam, "Do Students Know What They Know and What They Don't Know? Using a Four-Tier Diagnostic Test to Assess the Nature of Students' Alternative Conceptions," in J. Res Sci Educ, 2010, vol. 40, pp. 313-337

Fariyani, Q., Rusilowati, A., Sugianto. (2015). Four-Tier Multiple Choice Diagnostic Test Geometric Optic. Semarang: PPs Unnes.

Fariyani, Qisthi, Ani Rosilawati, dkk. (2017) "Four-Tier Diagnostic Test To Identify Miscopnceptions In Geometrical Optics." 2017, vol. 5.

Fratiwi dkk, 2016."The Transformation of The wo-Tier Test into Four Tier Test in Newton's Law Concept." 2016, vol 1.

Gurel et. al., "A Review and Comparison of Diagnostic Instruments to Identify Students'Misconceptions in Science," in Eurasia Journal of Mathematics Science and Technology Education, 2015, vol. 11, pp. 989-1008. J. K. Author, "Title of chapter in the book," in Title of His Published Book, xth ed. City of Publisher, Country if not USA: Abbrev. of Publisher, year, ch. $x$, sec. $x$, pp. $x x x-x x x$

Gurel, D. K., Eryilmaz, A., \& McDermott, L. C. 2015. A Review and Comparison of Diagnostic Instrumens to Misconceptions in Science. Eurasia Journal of Mathematics, Science, \& Technology Education, 11(5), 989-1008. doi: 10.12973/eurasia.2015.1369a

Kose, S. (2008). Diagnosing Student Misconceptions: Using Drawings as a Research Method. World Applied Sciences Journal, 3 (2), 283-293.

Law, J. F. \& Treagust, D. F. (2010). Diagnosis of Student Understanding of Content Specific Science Areas Using On-Line Two-Tier Diagnostic Tests. Australia: Curtin University.

Lin, S. (2004). "Development and Application of a Two-Tier Diagnostic Test for High School Students' Understanding of Flowering Plant Growth and Development". International Journal of Science and Mathematics Education, 2: 175-199. 
Sion, H. H. \& Janidi Jingan. (2008). Diagnostic assessment in three (3) core subjects for primary and secondary education (mathematics, english language and science): Hands-on workshop for government primary and secondary I and II (year $7 \&$ year teachers Negara Brunei Darussalam. $A$ Concept Paper. Department of Human Resource Development Department of Planning, Development and Research Ministry of Education. Diambil pada tanggal 3 Pebruari 2011, dari scholar.google.com.

Thiagarajan, S., Semmel, D. S., \& Semmel, M. I. (1974). "Instructional Development for Training Teacher of Exceptionl Children: A Sourcebook. National Center for Inprovement of Educational System (DHEW/OE), Washington, D.C.

Yusrizal dan Halim. 2017. 'The Effect Of The One-Tier, Two-Tier, And Three-Tier Diagnostic Test Toward The Students' Confidence And Understanding Toward The Concepts Of Atomic Nuclear" vol 22017

Zhongbao Zhao. (2013). "An Overview of Studieson Diagnostic Testing and its Implicationsfor the Development of Diagnostic Speaking Test”. International Journal of English Linguistics. Vol. 3 No. 1, 41-45. 